\title{
Early-stage changes in chemical phosphorus speciation induced by liming deforested soils
}

\author{
Ji-Suk Park ${ }^{1}$, Hee-Myong Ro ${ }^{1 *}$
}

${ }^{1}$ Department of Agricultural Biotechnology and Research Institute of Agriculture and Life Sciences, College of Agriculture and Life Sciences, Seoul National University. 1 Gwanak-ro, Gwanak-gu, Seoul 08826, Republic of Korea.*Corresponding author: hmro@snu.ac.kr

\begin{abstract}
A hypothesis of whether an increase in $\mathrm{Ca}^{2+}$ due to liming acid soils causes an increase in Ca-phosphates with a concomitant decrease in $\mathrm{Al}$ - and Fe-phosphates was tested on a relatively short-term time frame, as observed in the investigations of chemical phosphorus $(\mathrm{P})$ speciation. Soil samples were taken at a deforested site and split into three treatment groups: a control and two $\mathrm{CaCO}_{3}$ treatments $\left(0.1\right.$ and $0.4 \mathrm{~g} \mathrm{CaCO}_{3}$ in $100 \mathrm{~g}$ soil). Each soil was incubated at $25 \pm 2^{\circ} \mathrm{C}$ for 40 days. Inorganic-P was partitioned into three fractions: Fraction-A (Al- and occluded Fe-P), Fraction-B (non-occluded Fe- and adsorbed-P), and Fraction-C (Ca-P). The $\mathrm{pH}$ of $\mathrm{CaCO}_{3}$-treated soils decreased right after liming, indicating a probable formation of solid phosphate compounds. Available $\mathrm{P}$ in $\mathrm{CaCO}_{3}$-treated soils decreased from $0.67 \mathrm{mg} \mathrm{kg}^{-1}$ to control levels at the end of incubation. Total-P and organic$\mathrm{P}$ of $\mathrm{CaCO}_{3}$-treated soils were virtually the same as those of control soils, while inorganic-P varied. Fraction-A in both $\mathrm{CaCO}_{3}$-treated soils peaked at 10 days of incubation, and then decreased below control levels, while Fraction-B decreased abruptly right after liming, and thereafter gradually decreased. Liming decreased Fraction$\mathrm{C}$, and caused an increase in $\mathrm{Al}$ - and $\mathrm{Fe}-\mathrm{P}$ due to an increase in exchangeable $\mathrm{Al}^{3+}$ and $\mathrm{Fe}^{3+}$. Our results challenge the hypothesis by showing the unexpected opposite data for Al-, Fe- and Ca-P compounds at least in the early stage of equilibrium disturbances due to liming an acidic soil.
\end{abstract}

Keywords: Calcium, deforestation, equilibrium, fractionation, interconversion 


\section{Introduction}

Deforestation is the removal of trees in a forest where the land is thereafter converted to a non-forested land, entailing a potential threat to the health of terrestrial and aquatic ecosystems. The removal of trees without sufficient reforestation has led to unfavorable consequences, including loss of habitat, loss of biodiversity, and poor soil quality. Changes in soil chemical properties due to deforestation considerably decreased the levels of soil nutrients, $\mathrm{pH}$ and available phosphorus, since the lowering of soil $\mathrm{pH}$ alters nutrient availability and thereby affects plant growth and productivity in highly acidic soils (Zaman et al., 2010).

Phosphorous (P) has been recognized as a major limiting nutrient for sustaining the productivity and resilience of terrestrial ecosystems (Poeplau et al., 2016; Vásconez et al., 2018), and the availability and chemical form is very sensitive to changes in soil $\mathrm{pH}$. In acidic soils $\mathrm{Al}^{3+}$ and $\mathrm{Fe}^{3+}$ react extensively with phosphates $\left(\mathrm{H}_{2} \mathrm{PO}_{4}^{-}\right.$and $\left.\mathrm{HPO}_{4}{ }^{2-}\right)$ to form insoluble $\mathrm{Al}$ and $\mathrm{Fe}$ phosphate compounds (Ro and Cho, 2000; Verma et al., 2005; Redel et al., 2016), while in neutral and alkaline soils $\mathrm{Ca}^{2+}$ readily reacts with phosphates to form less insoluble Ca-P compounds (Lindsay, 1979). However, recent evidence suggests the possibility of conversion of Ca-P compounds into even more insoluble compounds, decreasing their solubilities (Mahdi et al., 2012).

In general, liming is known to increase the availability of $\mathrm{P}$ in acidic soils by stimulating mineralization of soil organic P pools (Haynes, 1982; Sharma et al., 2013). However, another line of investigation suggests that liming decreased soluble-P and labile-P until the $\mathrm{pH}$ reached about 6.5 (Delgado and Torrent, 2000), thus indicating the occurrence of chemical disturbances in the early stage of liming, contrary to the widely-held notion. This contrasting effect of liming obviously suggests that the solubility and interaction of each $\mathrm{P}$ compound predominantly governs its availability and chemical speciation in soils (Haynes, 1982; Mahdi et al., 2012; Saleem et al., 2017), and that the patterns of partitioning and chemical speciation of $\mathrm{P}$ would vary with time.

Liming with $\mathrm{CaCO}_{3}$ or $\mathrm{CaSO}_{4}$ is an effective way of increasing the soil $\mathrm{pH}$ of acidic soils, and has two major effects on the soil chemical status, since it adds a large amount of Ca ions (Fransson et al., 1999). Liming however, can reduce the availability of $\mathrm{P}$ in soils due to extensive interaction of $\mathrm{P}$ with $\mathrm{Ca}^{2+}, \mathrm{Al}^{3+}$ and $\mathrm{Fe}^{3+}$ ions (Machado and Silva, 2001), thus causing a shift in ionic composition. The changes in ionic composition due to changes in soil $\mathrm{pH}$ can in turn lead to a shift in chemical equilibria by increasing concentrations of dissolved $\mathrm{Ca}^{2+}$ and displaced hydrolytic $\mathrm{Fe}$ and $\mathrm{Al}$ species (hereafter, be referred to as $\mathrm{Al}^{3+}$ and $\mathrm{Fe}^{3+}$, respectively) that can decrease the availability of $\mathrm{P}$ in the soil solution (Ro and Cho, 2000). Since these reactions involve large number of chemical forms of $\mathrm{P}$ in soils, which are bound to metals or free cations and differ in their mobility and availability, the different $P$ species, such as labile $\mathrm{P}$, reductant $\mathrm{P}$, and metal-bound $\mathrm{P}$, coexist. Thus, the distribution of $\mathrm{P}$ species can be separated by different sequential extraction schemes, the so-called P-fractionations (Chang and Jackson, 1957; Kaiserli et al., 2002).

Nevertheless, the mechanism responsible for variations in $\mathrm{P}$ chemical speciation in soils due to liming is still not fully understood. Although a large majority of efforts has been so far directed to long-term effects of liming on the chemical P speciation (Patzold et al., 2013), too little attention has been paid to relatively short-term effects right after liming. The time-dependent relative thermodynamic stability and the kinetics of interconversion from various $\mathrm{P}$ compounds are also required. Moreover, a chemical disturbance caused by 
liming in turn triggers complex chemical reactions in which a large number of chemical interconversions among P compounds occurs. The series of sequential or parallel interconversion reactions that determines inorganic $\mathrm{P}$ speciation processes however, are still unresolved because of insufficient data or information on the Gibbs free energy of formation or the equilibrium constant for each binary combination of P compounds.

In addition, some recent evidence suggests an inconsistency in the effects of liming on the distribution of $\mathrm{Ca}-\mathrm{P}$ species and the availability of $\mathrm{P}$ (Machado and Silva, 2001; Mahdi et al., 2012). This situation necessitates a testing of the possibility of conversion of Ca-P compounds into less soluble compounds and/or concurrent formation of Al- and/or Fe-P compounds in order to bridge the knowledge gap for the effect of liming at least in the early stage of chemical disturbances. Therefore, we challenged the widely-held notion that $\mathrm{P}$ availability increases due to liming by hypothesizing that an increase in soil $\mathrm{pH}$ induced by liming would instantaneously disturb chemical equilibria among inorganic $\mathrm{P}$ species through extensive interactions with increased $\mathrm{Ca}^{2+}$ due to dissolution of $\mathrm{CaCO}_{3}$ and with displaced $\mathrm{Al}^{3+}$ and $\mathrm{Fe}^{3+}$. Here, we tested this hypothesis by conducting batch incubation experiments and determined the time-course distribution patterns of chemical $\mathrm{P}$ species by sequential $\mathrm{P}$ extraction and X-ray diffraction analysis. As evidenced by recent evidence of decreasing $\mathrm{P}$ availability and solubility (Machado and Silva, 2001; Mahdi et al., 2012), the response of the speciation and availability of $\mathrm{P}$ to liming practices should be reevaluated, particularly for forest tree nurseries for reforestation and forest management.

\section{Materials and Methods}

\subsection{Sampling sites and soil preparation}

The study site was located in the Seoul National University Forest, Mt. Backwoon, Jeollanam-do $\left(35^{\circ} 2^{\prime} \mathrm{N}\right.$, $\left.127^{\circ} 35^{\prime} \mathrm{E}\right)$. The deforestation site was clear-cut 5 years ago, mostly to allow cultivation of pitch pine (Pinus rigida Mill.). Soil samples (0-30 cm in depth) were taken in February 2012. Immediately after sampling, soil samples were air-dried at room temperature, passed through a $2 \mathrm{~mm}$ sieve, and mixed thoroughly. The physical and chemical properties of the soil were shown in Table 1.

Table 1. Some relevant physicochemical properties of

\begin{tabular}{|c|c|}
\hline Soil parameters & Values \\
\hline Texture $^{a}$ & Loam \\
\hline Bulk density $\left(\mathrm{Mg} \mathrm{m}^{-3}\right)$ & 1.1 \\
\hline $\mathrm{pH}\left(\right.$ soil: water $\left.=1: 5^{\mathrm{b}}\right)$ & 5.4 \\
\hline Organic carbon $\left(\mathrm{g} \mathrm{kg}^{-1}\right)$ & 44.5 \\
\hline Total P $\left(\mathrm{g} \mathrm{kg}^{-1}\right)$ & 0.26 \\
\hline Available $\mathrm{P}\left(\mathrm{mg} \mathrm{kg}^{-1}\right)$ & 0.78 \\
\hline $\mathrm{CEC}\left(\mathrm{cmol} \mathrm{kg}^{-1}\right)$ & 20.1 \\
\hline
\end{tabular}

2.2. Lime requirement

Lime requirement was determined by the incubation pH buffer curve method (Kuo, 1996). One hundred grams of an air-dried soil sample was placed into each 
of seven separate $250 \mathrm{~mL}$ Erlenmeyer flasks, and these samples were adjusted to field moisture capacity $\left(0.31 \mathrm{~m}^{3} \mathrm{~m}^{-3}\right)$ and mixed with calcium carbonate $(0,0.1,0.2,0.3,0.5,0.7$, and $0.9 \mathrm{~g})$. Each mixture was sealed with Parafilm ${ }^{\circledR}$, and was shaken at 120 rpm at $25 \pm 2{ }^{\circ} \mathrm{C}$ for 5 days. The soil was then dried at room temperature. The soil $\mathrm{pH}$ was measured potentiometrically in a 1:5 (w/v) soil:water suspension using a $\mathrm{pH}$ meter (Orion 3 star, Thermo Scientific, $\mathrm{NH}$, USA). The $\mathrm{pH}$ data were used to draw a $\mathrm{pH}$ buffer curve to obtain the lime requirement values for the desired target $\mathrm{pH}$.

\subsection{Batch incubation experiments}

In order to investigate the liming effect on the $\mathrm{pH}$ and $\mathrm{P}$ fractions on deforestation soil, $100 \mathrm{~g}$ of soil sample was transferred into $250 \mathrm{~mL}$ plastic bottles, and a total of 45 bottles were prepared for three treatments (control and adjustments to $\mathrm{pH} 6$ and 7) in triplicate with 5 destructive samplings. The soil samples were split into three treatments: a control and two lime-treated soils (adjusted to $\mathrm{pH} 6$ and 7, respectively), and each treatment group was preincubated at $25 \pm 2{ }^{\circ} \mathrm{C}$ in the dark. The deforestation soil was limed to the target $\mathrm{pH}$ by adding laboratory grade, powdered $\mathrm{CaCO}_{3}$. The soil water content was adjusted to $0.31 \mathrm{~m}^{3} \mathrm{~m}^{-3}$ (field capacity). After pre-incubation, two lime-treated soils were mixed with either $0.1 \mathrm{~g} \mathrm{CaCO}_{3}$ (referred to as low $\mathrm{CaCO}_{3}$ or LCC) or $0.4 \mathrm{~g} \mathrm{CaCO}_{3}$ (referred to as high $\mathrm{CaCO}_{3}$ or HCC), and these two terms represent adjustments to $\mathrm{pH} 6$ and 7, respectively. The bottles were incubated at $25 \pm 2{ }^{\circ} \mathrm{C}$ for 40 days. The soil water content was adjusted to maintain the field moisture capacity during the 40-day batch experiment by adding deionized water to the bottles as necessary to maintain their initial condition.

\subsection{Sampling and analyses of soils}

Triplicate soil samples for each treatment were prepared for analysis of the chemical properties at 0 ( 5 hours), 1, 10, 25, and 40 days of incubation. Soil samples were air-dried at room temperature, passed through a $2-\mathrm{mm}$ sieve, mixed thoroughly, and analyzed for soil $\mathrm{pH}$, total-P, organic-P, available-P, inorganic-P and exchangeable $\mathrm{Ca}^{2+}, \mathrm{Al}^{3+}$ and $\mathrm{Fe}^{3+}$. The soil $\mathrm{pH}$ was determined in a 1:5 (w/v) soil:water suspension using a $\mathrm{pH}$ meter (Orion 3 star, Thermo Scientific, USA). Total $\mathrm{P}$ was determined by the ammonium paramolybdate-vanadate colorimetric method after a perchloric acid digestion (Kuo, 1996) using a UV-visible spectrophotometer (UV-1601, Shimadzu, Japan). Organic P was determined by the ignition method (Saunders and Williams, 1955), and available P was determined by the Bray-1 procedure (Bray and Kurtz, 1945) using a UV-visible spectrophotometer.

The inorganic $\mathrm{P}$ was partitioned into three chemical fractions (Fraction-A, Fraction-B, and Fraction-C) according to Fractionation procedure (Chang and Jackson, 1957). Fraction-A denotes the $\mathrm{NaOH}$ extractable $\mathrm{P}$ fraction (a mixture of Al-P and occluded Fe- P) that is obtained from soil extracts with $1 \mathrm{M} \mathrm{NH}_{4} \mathrm{Cl}+$ $0.5 \mathrm{M} \mathrm{NH}_{4} \mathrm{~F}+0.1 \mathrm{M} \mathrm{NaOH}$. Fraction-B denotes the citrate-dithionite-bicarbonate extractable $\mathrm{P}$ fraction (a mixture of non-occluded Fe- $\mathrm{P}$ and adsorbed-P) that is obtained by adding $0.3 \mathrm{M} \mathrm{Na}_{3} \mathrm{C}_{6} \mathrm{H}_{5} \mathrm{O}_{7}+1 \mathrm{M} \mathrm{NaHCO}_{3}$ to the residue and heating the suspension in a water bath at $85^{\circ} \mathrm{C}$ and then adding $1 \mathrm{~g} \mathrm{Na}_{2} \mathrm{~S}_{2} \mathrm{O}_{4}$. Fraction$\mathrm{C}$ is referred to as the $\mathrm{H}_{2} \mathrm{SO}_{4}$ extractable $\mathrm{P}$ fraction (Ca-P) that is separated by adding $0.25 \mathrm{M} \mathrm{H}_{2} \mathrm{SO}_{4}$ and shaking for $1 \mathrm{~h}$. Saturated $\mathrm{NaCl}$ was used to wash the residue twice after each extraction step.

The $\mathrm{P}$ concentrations in each fraction were determined by the ascorbic acid method (Murphy and Riley, 1962). The unaccounted-for P was calculated from the difference in total $\mathrm{P}$ and the sum of inorganic 
P fractions. Exchangeable Ca was obtained by the $1 \mathrm{M}$ ammonium acetate $(\mathrm{pH} 7)$ method (Sumner and Miler, 1996), and exchangeable $\mathrm{Al}$ and Fe were obtained by the $1 \mathrm{M}$ potassium chloride, nitric acid method (Bertsch and Bloom, 1996). These exchangeable cations were measured using an ICP-OES (inductively coupled plasma-optical emission spectrometer, ICPS1000IV, Shimadzu, Japan).

To predict the time-course interconversion processes from the thermodynamic data and the presence of the crystalline P compounds available in the literature, the mineralogical composition of soil samples collected at a given time was analyzed using a Bruker AXS D8 ADVANCE with a DAVINCI design X-ray diffractometer ( $\mathrm{Cu} \mathrm{K} \alpha$ radiation with a $\lambda$ of $15.418 \AA)$, equipped with a 3 -circle goniometer. Samples were step scanned between 5 and $90^{\circ}(2 \theta)$ with an increment of $0.02^{\circ}$ and a $1 \mathrm{~s}$ counting time per step at room temperature. The mineralogical composition of a soil sample was identified by using the Bruker DIFFRAC plus software with the Joint Committee on Powder Diffraction Standards (JCPDS) PDF-1 and PDF-2 databases.

\subsection{Statistical analysis}

Data were analyzed using the General Linear Model procedures (SAS Institute, Version 9.3, Cary, NC, USA). The effects of two factors $\left(\mathrm{CaCO}_{3}\right.$ treatment and time) and interactions on $\mathrm{pH}$, total-P, organic-P, available-P, inorganic $\mathrm{P}$ fractions, and exchangeable cations were evaluated. A two-way analysis of variance (ANOVA) for a completely randomized design with three replications was performed to test for significant differences among the treatment means within a factor and for interactions between factors. The least significant difference (LSD) test at a confidence level of $p<0.05$ were used to separate means. The calculated $\mathrm{p}$ values for the two main factors and the interaction were shown in Table 2.

Table 2. Results of two-way analysis of variance (ANOVA) showing the $\mathrm{p}$ values for $\mathrm{pH}$, Total-P, Organic-P, Available-P, Inorganic-P and exchangeable cations as affected by $\mathrm{CaCO}_{3}$ treatment, incubation time and their interaction.

\begin{tabular}{|c|c|c|c|c|c|c|c|c|c|c|}
\hline \multirow[t]{2}{*}{ Factor } & \multirow[t]{2}{*}{$\mathrm{pH}$} & \multirow{2}{*}{$\begin{array}{c}\text { Total } \\
-\mathrm{P}\end{array}$} & \multirow{2}{*}{$\begin{array}{c}\text { Organic } \\
-\mathrm{P}\end{array}$} & \multirow{2}{*}{$\begin{array}{c}\text { Available } \\
\text {-P }\end{array}$} & \multicolumn{3}{|c|}{ Inorganic-P } & \multicolumn{3}{|c|}{ Exchangeable cations } \\
\hline & & & & & Fraction- $\mathrm{A}^{\mathrm{a}}$ & Fraction- $\mathrm{B}^{\mathrm{b}}$ & Fraction- $\mathrm{C}^{\mathrm{c}}$ & $\mathrm{Ca}^{2+}$ & $\mathrm{Al}^{3+}$ & $\mathrm{Fe}^{3+}$ \\
\hline $\mathrm{CaCO}_{3}$ & $<0.001$ & NS & NS & $<0.001$ & 0.002 & $<0.001$ & $<0.001$ & $<0.001$ & $<0.001$ & $<0.001$ \\
\hline Time & $<0.001$ & 0.008 & $<0.001$ & $<0.001$ & $<0.001$ & $<0.001$ & 0.005 & 0.002 & 0.019 & 0.030 \\
\hline $\begin{array}{c}\mathrm{CaCO}_{3} \mathrm{x} \\
\text { Time }\end{array}$ & $\mathrm{NS}^{\mathrm{d}}$ & NS & NS & NS & $<0.001$ & 0.019 & 0.019 & NS & $<0.001$ & NS \\
\hline
\end{tabular}

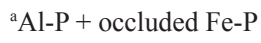

${ }^{\mathrm{b} N o n-o c c l u d e d ~ F e-P ~+~ a d s o r b e d-P ~}$

${ }^{\mathrm{C}} \mathrm{Ca}-\mathrm{P}$ of Inorganic P fractions

dNot significant 


\section{Results}

3.1. Effect of liming on P measures and exchangeable cations.

The soil $\mathrm{pH}$ initially increased up to 6.9 for the $\mathrm{HCC}$ treatments and 6.3 for the LCC treatments as compared with control soils ( $\mathrm{pH}$ of 5.5), and then quickly decreased to 6.7 for the former and 6.0 for the latter within 1 day of incubation (Figure 1). Total-P and organic-P of incubated soils did not change significantly in control and $\mathrm{CaCO}_{3}$-treated soils (Figures $2 \mathrm{~A}$ and $2 \mathrm{~B}$ ). The concentration of available-P was lower in $\mathrm{CaCO}_{3}$-treated soils than in control soils (Figure 2C), showing a negative relationship between liming and available-P in this study. However, the levels of available-P did not differ between the $\mathrm{CaCO}_{3}$-treated soils.

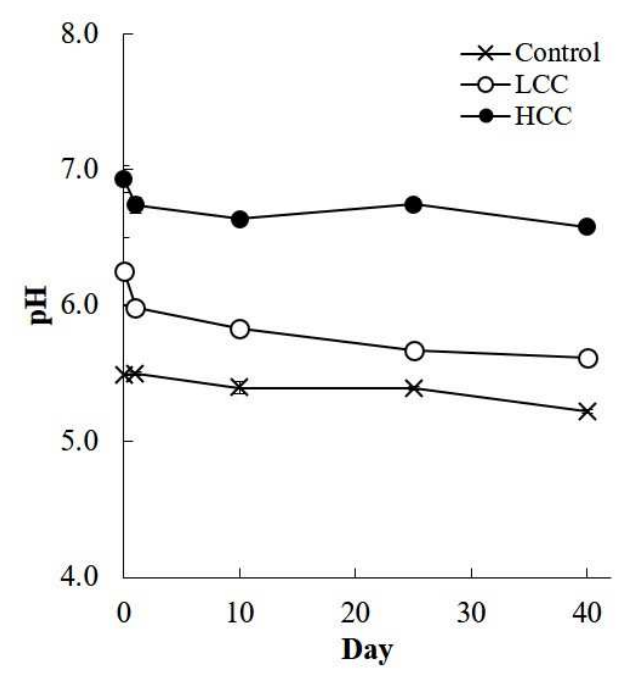

Figure 1. Temporal variations in the soil $\mathrm{pH}$ during batch incubation. Error bars indicate \pm standard deviation.
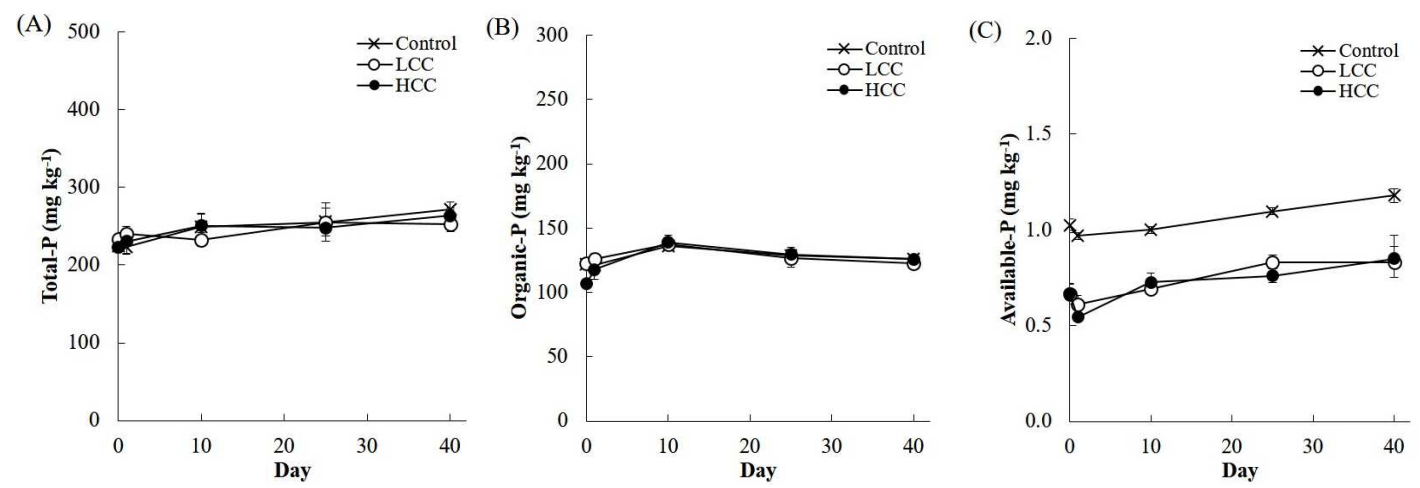

Figure 2. Temporal variations in the concentrations of (A) Total-P, (B) Organic-P and (C) Available-P during batch incubation. Error bars indicate \pm standard deviation. 
During incubation, the addition of $\mathrm{CaCO}_{3}$ caused an early increase in the levels of exchangeable $\mathrm{Ca}^{2+}, \mathrm{Al}^{3+}$ and $\mathrm{Fe}^{3+}$ ion species, and the increase was greater at higher rate of $\mathrm{CaCO}_{3}$ (Figure 3). Unlike the temporal variation patterns of $\mathrm{Al}^{3+}$ ions (Figure 3B), the initial increase in the concentrations of exchangeable $\mathrm{Fe}^{3+}$ ions decreased within 10 days of incubation and thereafter remained virtually unchanged (Figure 3C)
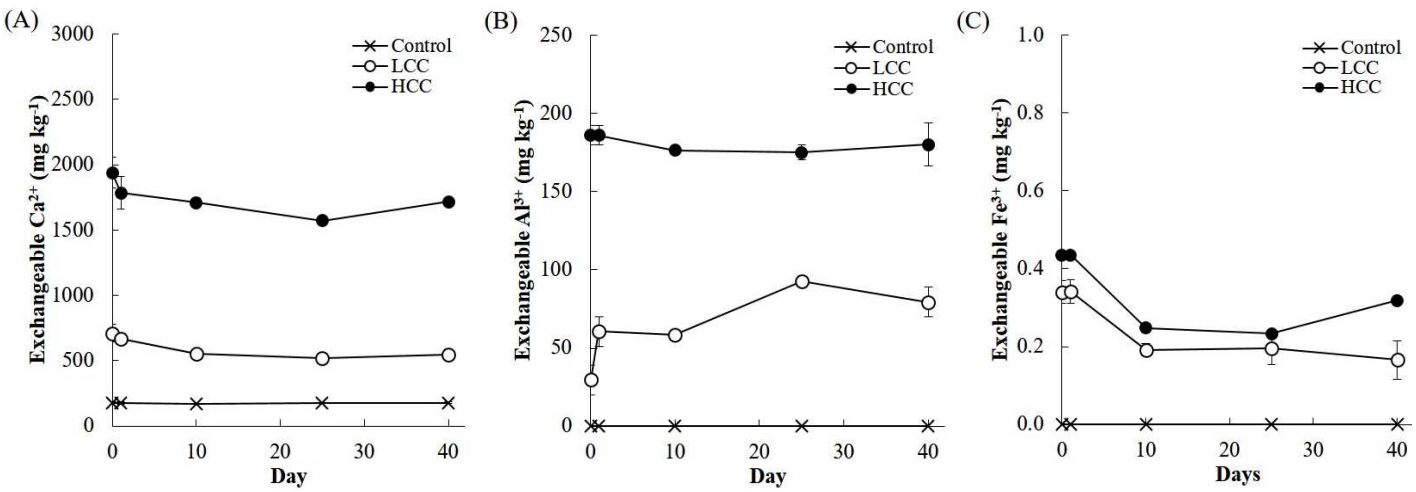

Figure 3. Temporal variations in the concentrations of exchangeable (A) $\mathrm{Ca}^{2+}$, (B) $\mathrm{Al}^{3+}$ and (C) $\mathrm{Fe}^{3+}$ during batch incubation. Error bars indicate \pm standard deviation.

\subsection{Effect of liming on inorganic P speciation.}

The levels of Fraction-A in $\mathrm{CaCO}_{3}$-treated soils peaked at 10 days of incubation, and then decreased soils within a day of incubation abruptly decreased at 10 days of incubation, and gradually increased thereafter (Figure 4B). During incubation, the levels of Fraction-C were lower in $\mathrm{CaCO}_{3}$-treated soils than in control soils (Figure 4C).
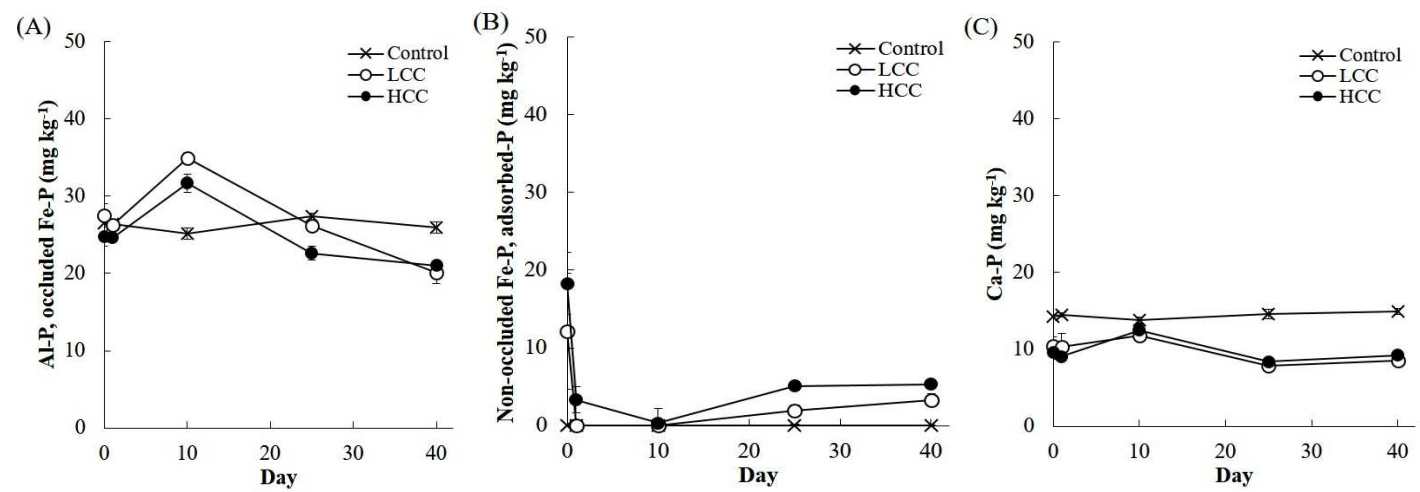

Figure 4. Temporal variations in the concentrations of inorganic $\mathrm{P}$ fractions during batch incubation: (A) Al-P + occluded Fe-P, (B) non-occluded Fe-P + adsorbed-P and (C) Ca-P. Error bars indicate \pm standard deviation. 
The mass-balance distribution of the unaccounted-for $\mathrm{P}$, which was not recovered by the sequential $\mathrm{P}$ fractionation procedure adopted herein, was calculated by subtracting the sum of inorganic-P fractions from the initial amount of total-P at each sampling time (Figure 5). Compared with control soils, the addition of $\mathrm{CaCO}_{3}$ decreased the portions of the unaccounted-for $\mathrm{P}$ during the early incubation (10 days of incubation) as consequences of the initial increase in Fraction-B and the subsequent increase in Fraction-A. At the end of incubation, however, the unaccounted-for $\mathrm{P}$ in $\mathrm{Ca}$ $\mathrm{CO}_{3}$-treated soils increased as a result of the concomitant decreases in Fraction-A and -C, although the portions of Fraction-B slightly increased. The addition of $\mathrm{CaCO}_{3}$ also decreased the portions of available-P (Figures $2 \mathrm{C}$ and 5), but did not affect those of organic-P.

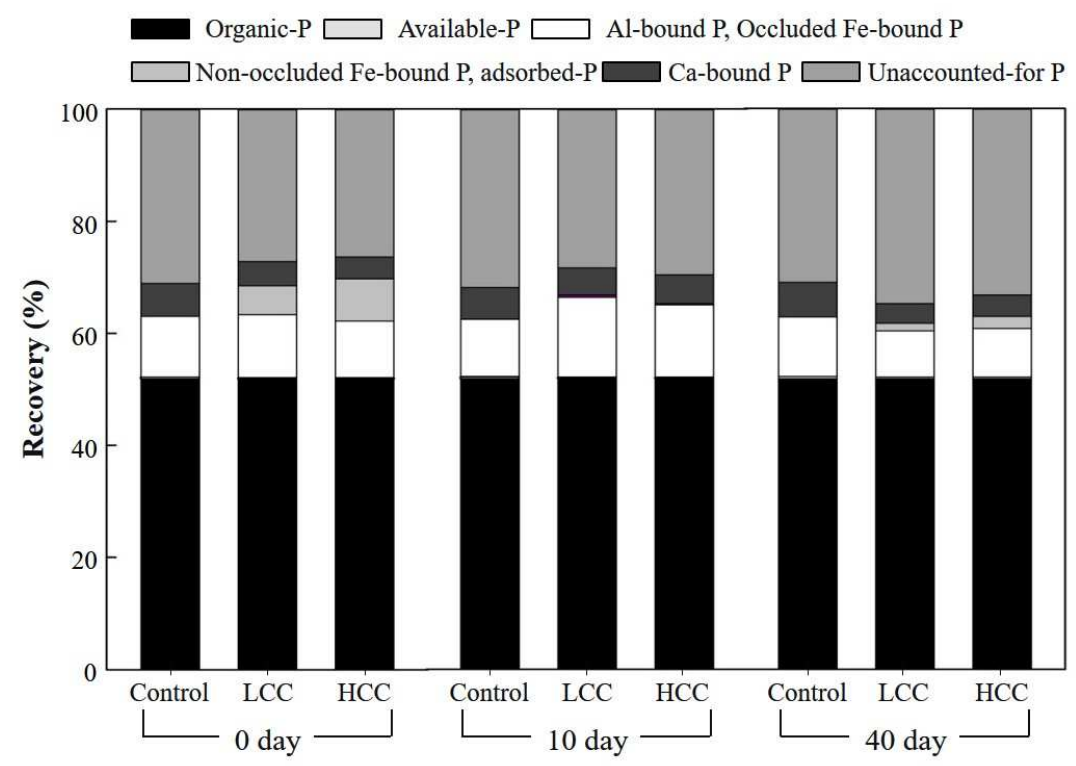

Figure 5. Time-course mass-balance distribution patterns of organic $\mathrm{P}$, available $\mathrm{P}, \mathrm{Al}$-bound $\mathrm{P}+$ occluded Febound $\mathrm{P}$, non-occluded Fe-bound $\mathrm{P}+$ adsorbed-P, Ca-bound $\mathrm{P}$ and unaccounted-for $\mathrm{P}$ fractions in soils as affected by the addition of $\mathrm{CaCO}_{3}$.

Compared with control soils, despite the relatively weak intensities of the peaks, liming obviously induced the conversion of Al-P compounds from crystalline to amorphous phase within a day of incubation and the subsequent formation of crystalline $\mathrm{AlPO}_{4}$ (berlinite) and its conversion into another crystalline hydrated Al-P compounds (Figure 6). 

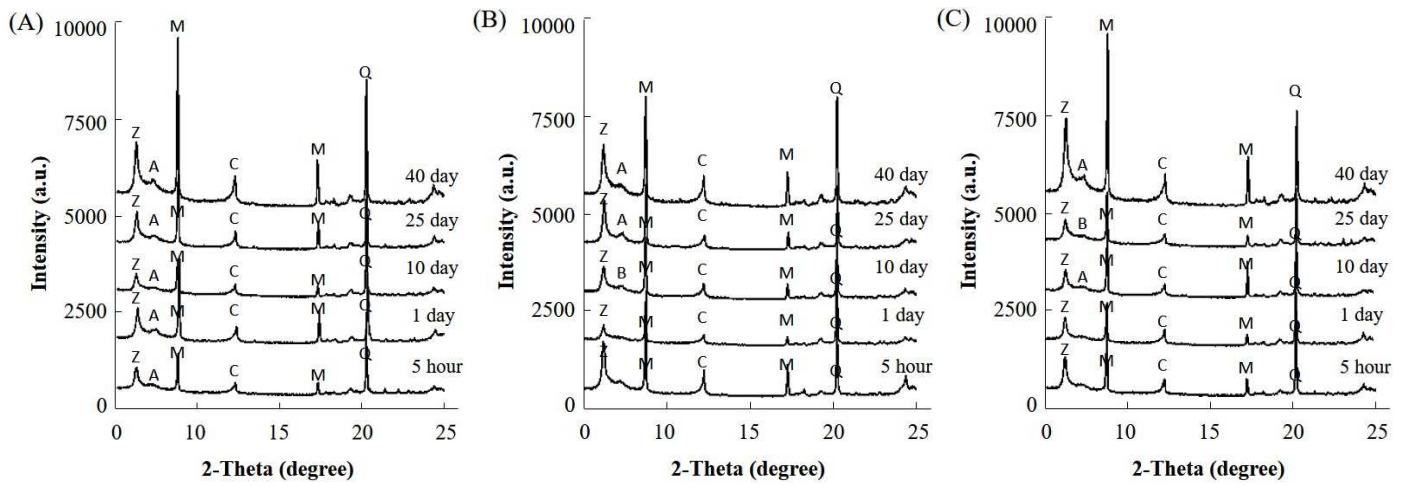

Figure 6. Temporal variations in X-ray diffraction patterns of (A) Control, (B) LCC and (C) HCC soils during batch incubation with spectral reference of the minerals identified. Different codes indicate the minerals from the JCPDS PDF database: (Z) Zeolite X PDF 01-089-8231, (A) AlMePO- $\alpha$ PDF 00-052-1383, (B) Berlinite PDF 00044-0044, (M) Muscovite PDF 00-007-0042, (C) Clinochlore PDF 00-060-0323 and (Q) Quartz PDF 00-046-1045.

\section{Discussion}

\subsection{Effect of liming on P measures and exchangeable cations.}

Compared with control soils, the $\mathrm{pH}$ initially increased in $\mathrm{CaCO}_{3}$-treated soils, and then quickly decreased within 1 day of incubation (Figure 1). In general, the extent of the increase in soil $\mathrm{pH}$ due to liming varies with soil buffering capacity, exchangeable ions such as $\mathrm{Al}^{3+}$ and $\mathrm{Fe}^{3+}$, and the equilibrium reactions among the inorganic P fractions (Hsu, 1964). Chaplain et al. (2011) ascribed the subsequent decrease in soil $\mathrm{pH}$ after liming to the protonation of variable charges and retention of positively charged hydroxylAl polymers. However, Ro and Cho (2000) observed that the formation of solid phosphate precipitates resulted in a lowering of soil $\mathrm{pH}$ due to $\mathrm{H}^{+}$production in both acidic soil systems.

During incubation, the levels of organic-P did not change in control and both $\mathrm{CaCO}_{3}$-treated soils. Several factors such as microbial activity, temperature, humidity, aeration, soil $\mathrm{pH}$, and plant species are known to affect mineralization of organic-P and immobilization of inorganic-P. Mckenzie et al. (1992) found that an increase in microbial activity increased mineralization of organic-P. However, the relative contribution of these factors to the balance between inorganic - and organic-P forms remains unclear, since the mechanisms associated with dynamics of organic$\mathrm{P}$ are difficult to determine due to the limitations in the available analytical procedures (Li et al., 2014) and the complexity of mineralization-immobilization turnover (Curtin and Syers, 2001).

In this study, available-P was inversely related to liming (Figure 2C), and this inverse relationship was not consistent with the results of most previous studies. In general, available-P increased due to the application of lime (Fageria, 1989). However, Pailles and Moody (1995) demonstrated a strong negative effect of $\mathrm{CaCO}_{3}$ content on available-P in estuarine and marine sediments. In contrast, Chang and Jackson (1958) observed that the application of lime increased the level of available-P in high phosphate soils but not in low 
phosphate soils. Hence, the presence of a causal relationship between $\mathrm{Ca}^{2+}$ content and available-P in the soil remains unclear. Several investigations reported that the minimum solubility of $\mathrm{P}$ was attained in the $\mathrm{pH}$ range between 5.5 and 6.5 due to the interaction with exchangeable cations (Haynes, 1982).

During incubation, the addition of $\mathrm{CaCO}_{3}$ caused an early increase in the levels of exchangeable $\mathrm{Ca}^{2+}, \mathrm{Al}^{3+}$ and $\mathrm{Fe}^{3+}$ ion species (Figure 3) due to dissolution of $\mathrm{CaCO}_{3}$ and the subsequent displacement of $\mathrm{Al}^{3+}$ and $\mathrm{Fe}^{3+}$ by exchangeable $\mathrm{Ca}^{2+}$ (Higgins et al., 2012), thus leading to a significant decrease in the levels of available-P (Figure 2C), due presumably to increased phosphate precipitation and/or adsorption reactions (Brady and Weil, 2010). Unlike the temporal variation patterns of $\mathrm{Al}^{3+}$ ions (Figure 3B), the initial increase in the concentrations of exchangeable $\mathrm{Fe}^{3+}$ ions decreased within 10 days of incubation and thereafter remained virtually unchanged (Figure 3C), indicating a probable formation of $\mathrm{Fe}$-containing compounds.

\subsection{Effect of liming on inorganic P speciation and mass-balance.}

The levels of Fraction-A (Al- and occluded Fe-P) in both $\mathrm{CaCO}_{3}$-treated soils peaked at 10 days of incubation, and then decreased finally below the control levels (Figure 4A). The initial increase in the levels of Fraction-A during the first 10 days of incubation could be explained in two ways. One is the direct formation of the Al-P compounds as a result of a marked increase in exchangeable $\mathrm{Al}^{3+}$ due to displacement and the conversion of hardly extractable Al-P compounds, such as berlinites and variscites, into more extractable $\mathrm{P}$ forms due to an increase in the solubility with increasing soil $\mathrm{pH}$ (Lindsay, 1979). The other explanation is the direct formation of the occluded Fe-P compounds, which was evidenced by the concurrent decrease in the concentration of exchangeable $\mathrm{Fe}^{3+}$
(Figure 3C). For the decrease in the levels of FractionA in the latter part of incubation, however, we could not provide direct evidence and logical explanation. A possible explanation might be the conversion into hardly soluble Al-P compounds as indicated by the equilibrium constants under neutral or alkaline conditions (Lindsay, 1979) or into the non-occluded Fe-P compounds as shown in Figure 4B.

The initial increase in the concentrations of Fraction$\mathrm{B}$ (non-occluded Fe- $\mathrm{P}$ and adsorbed-P) for $\mathrm{CaCO}_{3}-$ treated soils within a day of incubation (Figure 4B) indicated an early formation of the non-occluded Fe-P compounds by precipitation with displaced $\mathrm{Fe}^{3+}$ ions (Figure 3C). However, we could not eliminate the possibility of the conversion of the occluded Fe-P forms into more soluble forms due to an increase in soil $\mathrm{pH}$ (Lindsay, 1979), since the levels of Fraction A (Figure $4 \mathrm{~A}$ ) slightly decreased during the same period. In the latter stage of incubation, the levels of FractionB slightly increased (Figure 4B) while those of exchangeable $\mathrm{Fe}^{3+}$ remained virtually unchanged (Figure $3 \mathrm{C}$ ), and this phenomenon indicated the possibility of the conversion of the occluded Fe-P forms into the non-occluded forms, as corroborated by the concurrent decrease in the levels of Fraction-A (Figure 4A).

Our results obtained for Fraction-C (Ca-P) did not follow the widely-held belief that the level of Ca-P increases with liming. During incubation, the levels of Fraction-C were lower in $\mathrm{CaCO}_{3}$-treated soils than in control soils (Figure 4C), and this could be ascribed presumably to the conversion into more stable Ca-P compounds (not extractable with the extraction scheme herein) as a result of extensive interactions of phosphates with more exchangeable $\mathrm{Ca}^{2+}$ ions. The initial decrease in the levels of Ca-P compounds with the concurrent decrease in those of exchangeable $\mathrm{Ca}^{2+}$ (Figure 3A) provided experimental support for the conversion into more stable and less soluble Ca-P compounds. In general, the solubility of 
Ca-P compounds in the soil decreases as the $\mathrm{pH}$ increases (Lindsay, 1979). It is well-known that Ca-P compounds, such as mono-calcium phosphates and di-calcium phosphates, are easily converted into less soluble $\mathrm{P}$ compounds in soils at neutral or alkaline $\mathrm{pH}$ or $\mathrm{Ca}^{2+}$-rich conditions (Tan, 2000). However, Pan and Darvell (2009) suggested that complete reappraisal of the Ca-P system should be needed to solve the confusion arising from our reliance on the reported solubility because detailed and accurate knowledge of the chemical equilibria between the solid phase and its solubility is lacking.

Ro and Cho (2000) observed the initial formation of a very unstable amorphous $\mathrm{Al}-\mathrm{P}\left[\mathrm{Al}(\mathrm{OH}) \mathrm{HPO}_{4}\right]$ and its quick conversion to another amorphous or crystalline precipitate as a result of a series of acid-base titrations. Tunesi et al. (1999) demonstrated that $\mathrm{P}$ added to calcareous soils was considerably insolubilized within 5 weeks due to the formation of insoluble Ca-P precipitates, suggesting that $\mathrm{P}$ availability is reduced for soils having a high reservoir of exchangeable cations by forming insoluble P compounds. However, we cannot proceed further because relevant information on the solid phosphates and their thermodynamic data that are essential to postulating the course of chemical interconversion processes are mostly unavailable in the literature. In addition, since the temporal variations in the mass-balance of each cation species $\left(\mathrm{Al}^{3+}, \mathrm{Ca}^{2+}\right.$ and $\mathrm{Fe}^{3+}$ ) were not directly measured, we cannot fully explain the relative contribution of each cation species to the mass-balance distribution of each P species.

\section{Conclusions}

Our approach challenged the widely-held notion that the portion of Ca-P (Fraction-C) and the availability of $\mathrm{P}$ would increase in the presence of increased exchangeable $\mathrm{Ca}^{2+}$ ions after liming. Our results consistently revealed that a disturbance in chemical equilibria right after liming resulted in an unexpected decrease in Ca-P and $\mathrm{P}$ availability and a concomitant increase in exchangeable $\mathrm{Al}^{3+}$ and $\mathrm{Fe}^{3+}$ cation species, which contradicts current hypotheses on liming and $\mathrm{P}$ availability. Furthermore, within a day of incubation, a decrease in Ca-P was observed with a concomitant decrease in soil $\mathrm{pH}$ (an indicator of the formation of precipitates in the system) and exchangeable $\mathrm{Ca}^{2+}$ ions, indicating a probable formation of thermodynamically more stable solid phosphate compounds (i.e., $\mathrm{AlPO}_{4}$ ) and their interconversions, as identified in the X-ray diffractograms. However, investigations about the quantification of the solubility isotherms of various solid phosphate compounds using acid-base titrations and the effect of soil types and soil fertility with differing organic matter content on the mass-balance distribution of chemical P species need further study with the aim of confirming our results.

\section{Acknowledgements}

The Editor and the anonymous reviewers provided helpful comments and criticism that improved the manuscript. This research was funded by the Brain Korea 21 Plus Program, and by support from the "Cooperative Research Program for Agriculture Science and Technology Development (Project No. PJ01266702)” Rural Development Administration, Republic of Korea.

\section{References}

Bertsch, P.M., Bloom, P.R. 1996. Aluminum. In: D. L. Sparks DL, A. L. Page, P. A. Helmke, R. H. Loeppert, P. N. Soltanpour, M. A. Tabatabai, C. T. Johnston, M. E. Summer, J. M. Bartels, J. M. Bigham (eds). Methods of Soil Analysis, Part 3. Third Edition. American Society of Agronomy and Soil Science Society of America, Madison, WI, pp: 517-550. 
Brady, N.C., Weil, R.R. 2010. Elements of the nature and properties of soils. Third Edition. PrenticeHall, Upper Saddle River, NJ, 614 p.

Bray, R.H., Kurtz, L.T. 1945. Determination of total, organic and available forms of phosphorus in soils. Soil Sci. 59, 39-45.

Chang, S.C., Jackson, M.L. 1957. Fractionation of soil phosphorus. Soil Sci. 84, 133-144.

Chang, S.C., Jackson, M.L. 1958. Soil phosphorus fractions in some representative soils. Eur. J. Soil Sci. 9, 109-119.

Chaplain, V., Défossez, P., Delarue, G., Roger-Estrade, J., Dexter, A.R., Richard, G., Tessier, D. 2011. Impact of lime and mineral fertilizers on mechanical strength for various soil pHs. Geoderma. 167, 360-368.

Curtin, D., Syers, J. 2001. Lime-induced changes in indices of soil phosphate availability. Soil Sci. Soc. Am. J. 65, 147-152.

Delgado, A., Torrent, J. 2000. Phosphorus forms and desorption patterns in heavily fertilized calcareous and limed acid soils. Soil Sci. Soc. Am. J. 64, 2031-2037.

Fageria, N.K. 1989. Effects of phosphorus on growth, yield and nutrient accumulation in the common bean. Trop. Agric. 66, 249-255.

Fransson, A.M., Bergkvist, B., Tyler, G. 1999. Phosphorus solubility in an acid forest soil as influenced by form of applied phosphorus and liming. Scand. J. Forest Res. 14, 538-544.

Haynes, R.J. 1982. Effects of liming on phosphate availability in acid soils. Plant Soil. 68, 289-308.

Higgins, S., Morrison, S., Watson, C. 2012. Effect of annual applications of pelletized dolomitic lime on soil chemical properties and grass productivity. Soil Use Manage. 28, 62-69.
Hsu, P.H. 1964. Adsorption of phosphate by aluminum and iron in soils Soil Sci. Soc. Am. J. 28, 474-478.

Kaiserli, A., Voutsa, D., Samara, C. 2002. Phosphorus fractionation in lake sediments -Lakes Volvi and Koronia, N. Greece. Chemosphere 46, 1147-1155.

Kuo, S. 1996. Phosphorus. In: D.L. Sparks, A.L. Page, P.A. Helmke, R.H. Loeppert, P.N. Soltanpour, M.A. Tabatabai, C.T. Johnston, M.E. Summer, J.M. Bartels, J.M. Bigham (eds). Methods of Soil Analysis, Part 3. Third Edition. American Society of Agronomy and Soil Science Society of America, Madison, WI, pp. 869-919.

Li, G., Li, H., Leffelaar, P.A., Shen, J., Zhang, F. 2014. Characterization of phosphorus in animal manures collected from three (dairy, swine, and broiler) farms in China. PLoS One. 9, 1-8.

Lindsay, W.L. 1979. Chemical equilibria in soils. John Wiley \& Sons. Inc., New York, NY, 449 p.

Machado, P.L.O.A., Silva, C.A. 2001. Soil management under no-tillage systems in the tropics with special reference to Brazil. Nutr. Cycl. Agroecosys. $61,119-130$.

Mahdi, S.S., Talat, M.A., Dar, M.H., Hamid, A., Ahmad, L. 2012. Soil phosphorus fixation chemistry and role of phosphate solubilizing bacteria in enhancing its efficiency for sustainable cropping - A review. J. Pure Appl. Microbiol. 66, 1905-1911.

Mckenzie, R.H., Stewart, J.W.B., Dormaar, J.F., Schaalje, G.B. 1992. Long-term crop rotation and fertilizer effects on phosphorus transformations: II. In a luvisolic soil. Can. J. Soil Sci. 72, 581-589.

Murphy, J., Riley, J.P. 1962. A modified single solution method for the determination of phosphate in natural waters. Anal. Chim. Acta. 27, 31-36.

Pailles, C., Moody, P. 1995. Effect of experimental conditions on phosphorus extracted from estuarine and marine sediments. Mar. Freshw. Res. 46, 435-440. 
Pan, H.B., Darvell, B.W. 2009. Calcium phosphate solubility: the need for re-evaluation. Cryst. Growth Des. 9, 639-645.

Patzold, S., Hejcman, M., Barej, J., Schellberg, J. 2013. Soil phosphorus fractions after seven decades of fertilizer application in the rengen grassland experiment. J. Plant Nutr. Soil Sci. 176, 910 920.

Poeplau, C., Bolinder, M.A., Kirchmann, H., Kätterer, T. 2016. Phosphorus fertilization under nitrogen limitation can deplete soil carbon stocks: evidence from Swedish meta-replicated long-term field experiments. Biogeosciences. 13, 1119-1127.

Redel, Y., Cartes, P., Demanet, R., Velásquez, G., Poblete-Grant, P., Bol. R., Mora, M.L. 2016. Assessment of phosphorus status influenced by $\mathrm{Al}$ and Fe compounds in volcanic grassland soils. J. Soil Sci. Plant Nutr. 16, 490-506.

Ro, H.M., Cho, C.M. 2000. Diffusive phosphate transport in Al-rich acidic porous cation exchange system. Can. J. Soil Sci. 80, 551-560.

Saleem, A., Irshad, M., Hassan, A., Mahmood, Q., Egrinya Eneji, A. 2017. Extractability and bioavailability of phosphorus in soils amended with poultry manure co-composted with crop wastes. J. Soil Sci. Plant Nutr. 17, 609-623.

Saunders, W.H.M., Williams, E.G. 1955. Observations on the determination of total organic phosphorous in soils. Eur. J. Soil Sci. 6, 254-267.
Sharma, S.B., Sayyed, R.Z., Trivedi, M.H., Gobi, T.A. 2013. Phosphate solubilizing microbes: sustainable approach for managing phosphorus deficiency in agricultural soils. SpringerPlus. 2, 587.

Sumner, M.E., Miller, W.P. 1996. Cation exchange capacity and exchange coefficients. In: D. L. Sparks, A.L. Page, P.A. Helmke, R.H. Loeppert, P.N. Soltanpour, M.A. Tabatabai, C.T. Johnston, M.E. Summer, J.M. Bartels, J.M. Bigham (eds). Methods of Soil Analysis, Part 3. Third Edition. American Society of Agronomy and Soil Science Society of America, Madison, WI, pp. 1201-1229.

Tan, K.H. 2000. Principles of soil chemistry. Fourth Edition. CRC Press, New York, NY, 362 p.

Tunesi, S., Poggi, V., Gessa, C. 1999. Phosphate adsorption and precipitation in calcareous soils: the role of calcium ions in solution and carbonate minerals. Nutr. Cycl. Agroecosys. 53, 219-227.

Vásconez, G, Pinochet, D. 2018. Residual value of the phosphate added to ecuadorian and chilean soils with different phosphorus retention capacity. J. Soil Sci. Plant Nutr. 18, 60-72.

Verma, S., Subehia, S., Sharma, S. 2005. Phosphorus fractions in an acid soil continuously fertilized with mineral and organic fertilizers. Biol. Fertil. Soils. 41, 295-300.

Zaman, M., Osman, K.T., Haque, S.M.S. 2010. Comparative study of some soil properties in forested and deforested areas in Cox's Bazar and Rangamati Districts, Bangladesh. J. For. Res. 21, 319-322. 